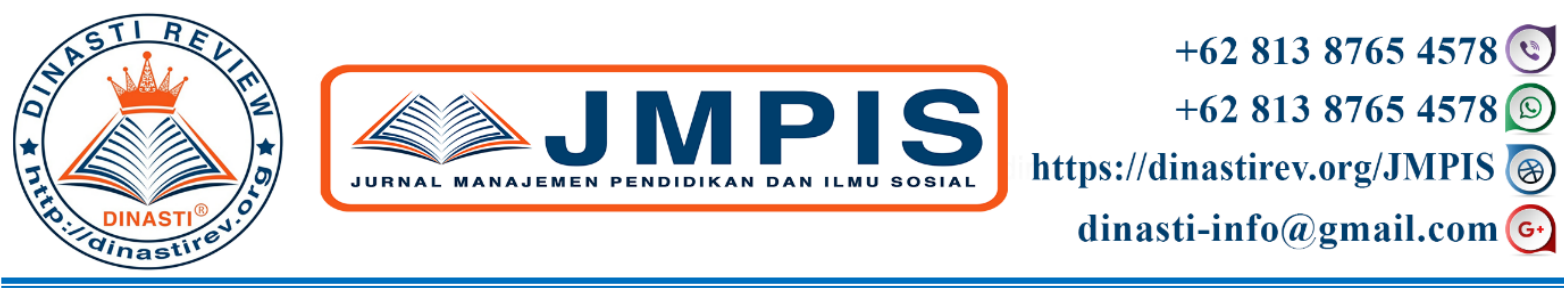

\title{
PENGARUH KEHADIRAN MINIMARKET MODERN TERHADAP PENDAPATAN PEDAGANG ECERAN \& GROSIR DI KOTA SAROLANGUN
}

\section{Herry Kurniawan}

Universitas Terbuka, Indonesia

ARTICLE INFORMATION

Received: 27 April 2020

Revised: 6 Mei 2020

Issued: 17 Mei 2020

Corresponding Author: First author

E-mail: elfrry2512@gmail.com

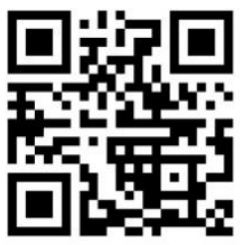

DOI:10.38035/JMPIS
Abstrak: Pertumbuhan minimarket modern di Indonesia beberapa tahun belakangan ini telah mengalami perkembangan yang pesat. Pertumbuhannya tidak hanya berada di pusat kota besar saja, tetapi sudah menyebar hingga ke daerah kota kecil. Hal ini yang terjadi di Kota Sarolangun, pertumbuhan minimarket modern yang mulai berkembang hingga ke kota kecil menyebabkan penyebarannya yang tidak beraturan antara satu minimarket dengan minimarket lainnya. Serta keberadaan minimarket yang berdekatan dengan pedagang eceran dan grosir yang berada dalam satu area jangkauan pelayanan akan sangat mempengaruhi preferensi masyarakat dalam berbelanja. Tujuan dari penelitian ini untuk mengetahui persepsi dan preferensi masyarakat terhadap minimarket maupun pedagang eceran dan grosir, juga untuk mengetahui pengaruh keberadaan minimarket modern terhadap pedagang eceran dan grosir berkaitan dengan jarak jangkauan pelayanannya, metode yang digunakan adalah survei lapangan dan metode penelitian kepustakaan bersifat kualitatif. Terdapat perubahan kecenderungan pada preferensi pemilihan tujuan berbelanja sebelum dan sesudah berdirinya minimarket modern di kawasan Kota Sarolangun.

Kata Kunci: Pengaruh, Minimarket Modern, Pedagang Eceran dan Grosir, Jangkauan Pelayanan.

\section{PENDAHULUAN}

Kehadiran minimarket di Indonesia mengalami perkembangan yang pesat pada dekade tahun ini. Perdagangan eceran (retail) dan grosir merupakan salah satu kegiatan sektor informal di bidang perdagangan yang sangat strategis di Indonesia. Besarnya kegiatan retail dan gosir yang skala besar maupun kecil mulai mudah di jumpai di setiap penjuru kota, baik di kawasan tengah kota maupun di pinggiran kota di Indonesia. Tingginya pertumbuhan penduduk di perkotaan menyebabkan berkurangnya lapangan pekerjaan di bidang formal. Hal 
inilah yang menyebabkan kegiatan sektor informal untuk dijadikan sebagai alternatif lahan mata pencaharian bagi masyarakat.

Pertumbuhan minimarket modern di Kota Sarolangun terbilang cukup pesat dan dimungkinkan semakin lama akan semakin memberikan dampak buruk bagi pedagang eceran dan grosir pada umumnya. Hal ini berkaitan dengan preferensi masyarakat yang memiliki kemungkinan untuk cenderung beralih berbelanja di minimarket modern. Jarak antara toko usaha kecil dan lokasi minimarket modern yang berada dalam satu jangkauan pelayanan juga sangat berpengaruh pada preferensi masyarakat dalam menentukan tempat berbelanja.

Menurut survei yang telah penulis lakukan terhadap salah satu toko eceran dan grosir yang bernama Toko Ceria Toserba yang merupakan anak perusahaan dari PT. Abadi Group di Kota Sarolangun, dari pengakuannya bahwa adanya pengaruh yang terjadi setelah hadirnya minimarket modern penjualannya menjadi menurun. Ini merupakan salah satu penyebab menjamurnya minimarket modern yang berdampak negatif bagi para pedagang eceran dan grosir di Kota Sarolangun. Dan masyarakat lebih memilih berbelanja di minimarket modern dengan alasan lebih praktis, lengkap dan nyaman atau sekedar hanya melihat-lihat saja karena harga masing-masing produk langsung tertera disitu. Hal ini juga dikeluhkan oleh para pedagang, karena umumnya para pedagang menjadikan usahanya sebagai mata pencarian utama dengan berkurangnya konsumen yang berbelanja tentunya akan mempengaruhi pendapatan serta keberlangsungan usaha mereka.

Dari fenomena yang terjadi di atas, penulis ingin mengetahui lebih jauh mengenai pendapatan para pedagang eceran dan grosir khususnya di Kota Sarolangun, adakah dampak pendapatan mereka baik sebelum dan sesudah adanya minimarket modern yang beroperasi di sekitar wilayah toko mereka. Sehingga dengan latar belakang yang diuraikan tersebut, maka penulis tertarik untuk melakukan penelitian tentang "Pengaruh Kehadiran Minimarket Modern Terhadap Pendapatan Pedagang Eceran dan Grosir di Kota Sarolangun".

\section{KAJIAN PUSTAKA}

Menurut Kamus Besar Bahasa Indonesia (2005: 849), "Pengaruh adalah daya yang ada atau timbul dari sesuatu (orang atau benda) yang ikut membentuk watak, kepercayaan atau perbuatan seseorang." Sementara itu, Surakhmad (1982:7) menyatakan bahwa pengaruh adalah kekuatan yang muncul dari suatu benda atau orang dan juga gejala dalam yang dapat memberikan perubahan terhadap apa-apa yang ada di sekelilingnya.

Dari pengertian di atas maka dapat disimpulkan bahwa pengaruh merupakan suatu daya atau kekuatan yang timbul dari sesuatu, baik itu orang maupun benda serta segala sesuatu yang ada di alam sehingga mempengaruhi apa-apa yang ada di sekitarnya. Maka pengertian pengaruh dari minimarket modern terhadap pendapatan pedagang eceran dan grosir dapat diartikan sebagai daya yang dapat mengubah keberlangsungan yang biasa terjadi di pedagang eceran dan gosir, baik dari segi pendapatan, penjualan, dan lain sebagainya.

\section{METODE PENELITIAN}

\section{A. Pendekatan Penelitian}

Metode penelitian dalam penelitian ini adalah dengan survei lapangan dan metode penelitian kepustakaan bersifat kualitatif. Adapun metode yang digunakan adalah metode 
kualitatif. Istilah kualitatif, pada mulanya bersumber pada pengamatan kualitatif yaitu pengamatan yang menunjuk pada sikap alamiah dan perhitungannya atas dasar jumlah. Penelitian kualitatif, menekankan kepada tatacara penggunaan alat dan teknik yang berorientasi pada paradigma alamiah.

Metode penelitian kualitatif disebut sebagai metode artistik, karena proses penelitian lebih bersifat seni (kurang terpola) dan disebut sebagai metode imperative karena data hasil penelitian lebih berkenaan dengan interprestasi terhadap data yang ditemukan di lapangan. Metode kualitatif digunakan untuk mendapat data yang mendalam, suatu data yang mengandung makna sebenarnya. Pendekatan kualitatif artinya data yang dikumpulkan bukan berupa angka-angka, melainkan data tersebut berasal dari naskah wawancara, catatan lapangan, dokumen pribadi,dan dokumen resmi lainnya. Sehingga yang menjadi tujuan dari penelitian kualitatif ini adalah menggambarkan realita empiric dibalik fenomena secara mendalam, rinci, tuntas. Pola yang digunakan dalam penelitian ini yaitu bersifat deskriptif kualitatif.

Pendekatan yang peneliti gunakan adalah kualitatif deskriptif bertujuan untuk menemukan fakta, kemudian dilanjutkan dengan menemukan masalah, kemudian menuju pada identifikasi masalah dan akhirnya menuju kepada penyelesaian masalah.

\section{B. Subjek Penelitian}

Subjek Penelitian adalah orang yang benar-benar mengetahui permasalahan yang akan diteliti. Subjek Penelitian merupakan orang yang menjadi narasumber (pedagang eceran dan gosir) untuk memberikan informasi terkait tentang dampak minimarket modern di Kota Sarolangun.

\section{Lokasi Penelitian}

Lokasi penelitian ini dilakukan dari lingkungan pasar di Kota Sarolangun Kabupaten Sarolangun, Provinsi Jambi.

\section{Sumber Data}

\section{Data Primer}

Data primer merupakan data yang diperoleh dari masyarakat Kota Sarolangun. Teknik yang digunakan dalam mengumpulkan data primer dalam penelitian ini adalah melalui wawancara. Wawancara merupakan salah satu Teknik pengumpulan data dengan caramelakukan tanya jawab secara lisan dan langsung kepada pedagang eceran dan gosir antara dua orang atau lebih.

\section{Data Sekunder}

Data sekunder diperoleh melalui studi kepustakaan. Studi kepustakaan dilakukan melalui penelusuran bahan pustaka resmi, penelusuran internet dan studi dokumentasi berkas-berkas penting dan institusi dengan mengutip dari sumber yang ada.

\section{E. Teknik dan Instrumen Pengumpulan Data}

Dalam mencari data-data, dan informasi yang berupa fakta harus memperhatikan teknik pengumpulan data yang dinilai paling tepat. Sehingga informasi yang di dapat benar-benar valid dan reliabel. Seperti halnya data terdiri atas data primer dan data 
sekunder, maka teknik pengumpulannya pun terdiri dari dua yaitu pengumpulan data primer dengan menggunakan teknik pengumpulan data melalui wawancara, yaitu pengumpulan data secara langsung di lapangan oleh peneliti sendiri dan pengumpulan data sekunder melalui observasi atau kepustakaan (library research), yaitu pengumpulan data tidak secara langsung di lapangan, data diperoleh dari pihak lain yang sudah mengumpulkannya terlebih dahulu, serta data yang di dokumentasikan.

a) Observasi

Observasi adalah suatu proses pengambilan data yang dilakukan dengan cara pengamatan secara sistematis terhadap obyek penelitian yang diteliti dengan cara langsung dant erencana bukan karena kebetulan. Data observasi berupa deskripsi yang faktual, cermat dan terinci mengenai keadaan Kota Sarolangun.

b) Wawancara

Wawancara adalah pengumpulan data melalui proses dialog pewawancaraan dengan responden. Metode wawancara ini adalah bertanya secara lisan kepada pedagang eceran dan grosir di Kota Sarolangun untuk mendapatkan jawaban atau keterangan. Dalam hal ini pertanyaan secara lisan yang diajukan oleh penulis kepada para pedagang dan grosir di Kota Sarolangun dengan maksud agar mau memberikan jawaban akan keterangan atas pertanyaan yang diajukan oleh penulis.Untuk memudahkan peneliti dalam melakukan penelitian maka peneliti membuat variable dan indikator untuk menuntun peneliti dalam melakukan pengumpulan data. Variabel dan Indikator penelitian ini adalah sebagai berikut:

\begin{tabular}{|l|l|}
\hline \multicolumn{1}{|c|}{ Variabel } & \multicolumn{1}{c|}{ Indikator } \\
\hline 1. Pengaruh hadirnya minimarket & a. Anggapan pedagang \\
modern & b. Beralihnya konsumen \\
& c. Promosi potongan harga \\
& d. Promosi pemberian bonus \\
& e. Pengaruh positif dan negatif \\
\hline $\begin{array}{l}\text { 2. Pendapatan pedagang eceran } \\
\text { dan grosir }\end{array}$ & a. Menurunnya omset penjualan \\
& b. Hasil pendapatan per hari \\
& c. Persentase pendapatan \\
\hline
\end{tabular}

Sumber data: Analis pribadi peneliti, 2020.

c) Dokumentasi

Dokumentasi ditujukan untuk memperoleh data langsung dari tempat penelitian, meliputi buku-buku yang relevan, peraturan-peraturan, laporan kegiatan, foto-foto, data yang relevan penelitian. Metode ini untuk mencatat data-data sumber yang tersedia dalam bentuk dokumen-dokumen atau arsip-arsip lainnya. Data dapat diperoleh penulis adalah gambaran pedagang eceran dan grosir Kota Sarolangun.

\section{F. Analis Data}

Penelitian ini adalah penelitian deskriptif, dengan lebih banyak bersifat uraian dari hasil wawancara dan studi dokumentasi. Data yang telah diperoleh akan dianalisis 
secara kualitatif serta diuraikan dalam bentuk deskriptif. Adapun beberapa langkahlangkah analisis data sebagai berikut:

1) Reduksi data, yaitu sebagai proses seleksi, pemfokusan, pengabstrakan, transformasi data kasar yang ada di lapangan langsung, dan diteruskan pada waktu pengumpulan data, dengan demikian reduksi data dimulai sejak peneliti memfokuskan wilayah penelitian.

2) Penyajian data, yaitu rangkaian organisasi informasi yang memungkinkan penelitian dilakukan. Penyajian data diperoleh berbagai jenis, jaringan kerja, keterkaitan kegiatan atau tabel.

3) Penarikan kesimpulan, yaitu dalam pengumpulan data, peneliti harus mengerti dan tanggap terhadap sesuatu yang diteliti langsung di lapangan dengan menyusun polapola pengarahan dan sebab akibat.

Berdasarkan keterangan di atas, maka setiap tahap dalam proses tersebut dilakukan untuk mendapatkan keabsahan data dengan menelaah seluruh data yang ada dari berbagai sumber yang telah didapat dari lapangan dan dokumen pribadi, dokumen resmi, gambar, foto dan sebagainya melalui metode wawancara yang didukung dengan studi dokumentasi.

\section{HASIL DAN PEMBAHASAN}

Dalam menjalankan bisnis, adanya persaingan pasar memang bukan hal yang baru, baik usaha yang memang memiliki peluang pasar cukup bagus atau peluang usaha yang pasarnya tidak terlalu bagus. Banyak cara yang mereka lakukan agar usahanya tidak kalah bersaing dengan peluang usaha lainnya, sehingga masih bisa bertahan bahkan berkembang ditengah persaingan pasar yang semakin ramai. Dalam hal ini saya mengamati salah satu perusahaan yang berada di lingkungan tempat saya tinggal, yaitu PT. Abadi Group Ceria Toserba guna memenangkan dan mempertahankan pelanggan di Kota Sarolangun. Perusahaan tersebut dalam menerapkan strategi bersaing dengan para kompetitor untuk merebut pasar dengan melakukan berbagai strategi pemasaran yang dimana perusahaan itu memiliki bidang pemasaran yang bertugas mencapai target pemasaran dan penjualan.

Seiring dengan perkembangan teknologi informasi yang semakin berkembang, maka semakin bertambah pula kompetisi diantara perusahaan-perusahaan sehingga perusahaan berusaha terus meningkatkan kemampuannya untuk dapat bertahan didalam persaingan yang semakin kompetitif. Perusahaan yang mampu bertahan dalam persaingan adalah perusahaan yang dapat menyesuaikan diri pada perubahan-perubahan yang terjadi dalam dunia bisnis. Perkembangan teknologi adalah sesuatu yang tidak bisa kita hindari. Berkembangnya teknologi harus disikapi perusahaan dengan memanfaatkan teknologi yang ada dalam menjalankan usahanya. Perusahaan bisa memanfaatkan teknologi untuk keperluan promosi dan komunikasi dengan konsumen.

Jumlah Minimarket di Kota Sarolangun

\begin{tabular}{|c|c|}
\hline Nama Minimarket & Jumlah Unit \\
\hline Indomart & 3 Unit \\
\hline Alfamart & 8 Unit \\
\hline Ceria Toserba & 1 Unit \\
\hline Jumlah & 12 Unit \\
\hline
\end{tabular}


Sumber data: Analis pribadi peneliti, 2020.

Pada waktu itu, perusahaan ini menjadi primadona karena merupakan minimarket terbesar, terlengkap dan termurah di kota Sarolangun sebelum berkembangnya minimarket modern masuk di kota ini, yaitu Alfamart dan Indomart yang hampir berada di setiap sudut kota tempat keramaian. Dahulu hampir setiap hari terjadi antrian masyarakat untuk berbelanja di Ceria Toserba. Namun dengan masuknya minimarket modern Alfamart dan Indomart membuat penjualan di Ceria Toserba semakin lama semakin sepi peminat. Hal ini disebabkan karena masyarakat sekarang lebih memilih yang praktis, efektif dan dan efisien baik dalam hal waktu atau anggaran belanja. Memang dalam hal harga bersaing antara Ceria Toserba dengan kedua minimarket modern di Sarolangun ini, tetapi dalam hal pemasaran lebih unggul minimarket modern dengan iming-iming memberikan diskon atau potongan harga terhadap barang-barang tertentu yang hampir setiap waktu selalu berubah-ubah, terlebih pada hari jumat sampai dengan minggu promosi yang diberikan lebih menarik konsumen lagi. Pelayanan pegawai yang ramah dan keberadaan tokonya yang hampir disetiap sudut keramaian ada membuat peminat juga semakin ramai. Berbeda halnya dengan Ceria Toserba yang mana pegawainya kadang kurang ramah kepada pengunjung dan tokonya hanya ada satu tempat yang lokasinya disekitar pasar yang kadang membuat pengunjung memperhitungkan waktu yang ditempuh jika rumahnya berada di jarak yang cukup jauh.

Strategi adalah sarana bersama dengan tujuan jangka panjang hendak dicapai (David, 2009). Strategi merupakan alat untuk mencapai tujuan perusahaan dalam kaitannya dengan tujuan jangka panjang, program tindak lanjut, serta prioritas alokasi sumber daya (Chandler,2002). Strategi akan memaksimalkan keunggulan kompetitif dan meminimalkan keterbatasan bersaing. Strategi merupakan tindakan yang bersifat incremental (terus meningkat) dan terus menerus, serta dilakukan berdasarkan sudut pandang tentang apa yang diharapkan pelanggan dimasa depan(Umar, 2003).

Dalam rangka mempertahankan supaya perusahaan tidak terjadi likuidasi, maka PT. Abadi Group Ceria Toserba melakukan strategi bisnis untuk menghadapi persaingan, diantaranya dengan cara :

\section{Mengamati pasar dan kenali pesaing}

Dalam menghadapi kompetitor, terlebih dulu melihat potensi pasar yang ada. Mencari tahu siapa pesaing yang kompeten saat ini, sehingga tidak salah langkah dalam menentukan strategi. Dengan mengetahui siapa pesaing, secara tidak langsung menentukan bagaimana cara menghadapinya. Perubahan minat dan kebutuhan para konsumen, tentunya menjadi salah satu faktor penting yang perlu Anda perhatikan.

2. Menciptakan produk yang berbeda

Inovasi sangat penting. Dengan menciptakan produk yang unik dan belum ada dipasaran, maka produk memiliki nilai lebih dimata konsumen. Produk yang unik dan berbeda, memiliki ciri khas tertentu dan daya tarik tersendiri bagi para konsumen. Sehingga mereka lebih mengenali produk dan memilih produk tersebut dibandingkan produk lainnya yang ada dipasaran. 
3. Menonjolkan keunggulan produk perusahaan

Dengan cara mempertahankan kualitas produk atau pelayanan prima selama ini maka dapat menawarkan produk kepada konsumen, sehingga loyalitas konsumen terhadap produk perusahaan akan semakin meningkat.

\section{Mempelajarai kelebihan dan kelemahan pesaing}

Dengan mengetahui ilustrasi menghadapi persaingan pasar kelebihan apa yang dimiliki pesaing dan memanfaatkan kelemahan pesaing sebagai peluang untuk memenangkan persaingan pasar dengan tidak membuat pernyataan atau mengeluarkan pendapat yang menjatuhkan pesaing. Menciptakan produk yang tidak diciptakan pesaing atau berikan pelayanan yang tidak disediakan oleh pesaing. Sebab dengan menawarkan apa yang tidak dimiliki pesaing, maka peluang untuk memenangkan pasar semakin terbuka.

\section{Mempertahankan kekuatan produk}

Setelah mengetahui kelebihan dan kekurangan kompetito, ada baiknya bila mempertahankan kekuatan produk yang dimiliki untuk menjaga loyalitas para konsumen. Kunci inilah yang mengantarkan produk Pepsodent sampai hari ini berhasil menguasai pasar dan menjadi salah satu merk pasta gigi yang banyak dipilih para konsumen. Mempertimbangkan pentingnya memperluas pasar seperti menambahkan jenis produk dengan perencanaan target pasar yang baru. Sebagai contoh, jika selama ini target hanya konsumen remaja saja, maka menambahkan produk yang sering digunakan oleh ibu rumah tangga, sehingga hal tersebut dapat memperluas pasar.

\section{Menawarkan harga bersaing}

Menawarkan harga yang kompetitif, artinya, harga yang ditawarkan dari produk atau jasa lebih murah dari harga pesaing. Memberikan harga yang bersaing, bukan berarti harus menurunkan harga dan memperbesar kerugian usaha. Strategi ini bisa dilakukan dengan cara memberikan bonus untuk pembelian tertentu. Misalnya bila pesaing menjual produk dengan harga yang lebih murah, maka untuk menghadapinya dengan menawarkan bonus "beli 2 gratis 1 ".

\section{Mempromosikan produk perusahaan}

Melakukan promosi yang tepat. Sebelum memilih jenis promos, dilakukan riset terhadap para pesaing terlebih dahulu. Cara ini masih sering digunakan para pelaku usaha, karena minat konsumen untuk berburu barang-barang diskon masih sangat tinggi.

\section{Berani ambil resiko}

Untuk menarik minat konsumen, banyak pelaku usaha yang mengambil tantangan besar untuk meningkatkan daya saing bisnisnya. Strategi ini bisa dijalankan para konsumen dengan menawarkan inovasi-inovasi baru yang belum pernah ditemui para konsumen. 
Misalnya seperti memproduksi barang atau jasa unik yang belum ada di pasaran, atau bisa juga mengadakan event promosi besar-besaran yang melibatkan para konsumen.

\section{Mengembangkan Modal Manusia}

Pengembangan Sumber Daya Manusia (SDM) merupakan suatu hal yang urgen. Kualitas SDM berhubungan dengan produk yang dihasilkan, jika diproduksi oleh SDM yang berkualitas, maka produk yang dihasilkan adalah produk yang berkualitas. Mengacu pada pengetahuan dan kemampuan tenaga kerja perusahaan. Dengan kata lain, karyawan dipandang sebagai sumber modal. Salah satu sarana mengembangkan modal manusia ialah program pelatihan dan pengembangan. Memberikan pelayanan yang baik untuk memenangkan persaingan bisnis dengan mulai dari membuat SOP pelayanan dan berikan training ke seluruh karyawan. Minta karyawan untuk melayani konsumen dengan baik, mulai dari senyum dan akhiri dengan senyum kembali.

\section{Keunggulan Lokasi}

Perusahaan mendirikan tempat untuk penjulannya tidak hanya di satu tempat, tetapi juga membuka cabang ditempat lain yang terjangkau oleh konsumen. Keunggulan lokasi lainnya termasuk akses kepada peralatan atau sumber daya penting dan kepada pelanggan.

\section{Memandang kompetisi sebagai sebuah energi}

Kata kompetisi banyak ditafsirkan sebagai sebuah drama yang selalu melahirkan "Pemenang" sekaligus mencetak sekumpulan "Orang Kalah". Sebagai konsekuensinya, "Pemenang" akan ditafsirkan sebagai sosok yang menjulang di puncak kejayaan, yang akan dipandang dengan wajah menengadah oleh kaum "Terkalahkan". Sungguh menyedihkan bila alam semesta ini pada akhirnya dikotak-kotakkan sebagai winnerlooser.

Persaingan bisnis merupakan sebuah kompetisi antara para penjual yang sama-sama berusaha ingin mendapat keuntungan, pangsa pasar, serta jumlah penjualan yang tinggi. Persaingan bisnis ini sudah menjadi sesuatu yang wajib dalam berbisnis pelaku bisnis termasuk pelaku bisnis online. Tetapi dalam hal ini, belum bias dijalankan di Kota Sarolangun karena terbatasnya akses untuk memainkan bisnis online. Harapannya dengan persaingan bisnis di era modern ini dapat disikapi positif antara para pelaku bisnis dan juga oleh konsumen itu sendiri.

\section{KESIMPULAN DAN SARAN}

Berdasarkan Hasil Analisis dan pembahasan maka dapat disimpulkan bahwa:

a. Persepsi dan preferensi konsumen

Persepsi dan preferensi konsumen berkaitan dengan performa yang diberikan oleh minimarket modern dan juga pedagang eceran dan grosir memberikan dampak yang tentunya menjadi faktor utama dalam penilaian masyarakat untuk menentukan preferensi berbelanja mereka dikarenakan persepsi yang didapat bisa berbeda-beda. Persepsi dan preferensi yang ditarik disini berdasarkan hasil dari kuesioner dalam kolom kinerja dan 
kepentingan yang saling berkaitan sehingga menciptakan persepsi kepada konsumen yang pada akhirnya menjadi alasan mereka memilih salah satu dari minimarket modern dan juga pedagang eceran dan grosir. Dalam pemilihan tersebut disebutlah preferensi dalam berbelanja yang berdasarkan persepsi.

b.Pengaruh minimarket terhadap pedagang eceran dan grosir berkaitan jarak jangkau pelayanan

Berdasarkan jangkauan pelayanan, dapat diketahui bahwa semakin besar jangkauan minimarket, maka akan semakin banyak toko yang terfriksi dengan jangkauan pelayanannya. Berdasarkan penelitian, semakin jauh pedagang eceran dan grosir terhadap minimarket modern, pengaruh yang ditimbulkan semakin kecil. Namun, semakin dekat pedagang eceran dan grosir dengan minimarket modern maka pengaruhnya semakin besar terjadi pada jumlah konsumen yang datang setiap harinya. Radius jangkauan minimarket yang besar berdampak bagi pedagang eceran dan grosir yang berada di dalam jalan lingkungan ataupun pedagang eceran dan grosir karena pelanggan mereka yang berada pada radius jangkauan paling jauh lebih memilih berbelanja di minimarket modern daripada di pedagang eceran dan grosir. Sedangkan untuk pedagang eceran dan grosir yang berada pada poros jalan utama tidak terlalu berpengaruh dikarenakan rata-rata pelanggan mereka ratarata yang bertempat tinggal jauh dan hanya singgah untuk berbelanja dengan cepat.

Meninjau langsung pada RT dan RW Kota Sarolangun yang masuk menjadi kawasan sub pusat perdagangan dan jasa. Hal ini tentunya menjadi dampak perkembangan ekonomi ke kawasan tersebut. Sehingga perkembangan minimarket modern akan terus ada sedangkan eksistensi pedagang eceran dan grosir akan kian menurun.

\section{DAFTAR RUJUKAN}

Ali, Hapzi. 2018. Metodologi Penelitian. [Online] https://hapzi-ali.com/daftar-ebook/ebookmetodologi-penelitian.

Ali, Hapzi dan Nandan Limakrisna. 2018. Metodologi Penelitian: Petunjuk Praktis untuk Pemecahan Masalah Bisnis, Penyusunan Skripsi, Tesis dan Disertasi.

Tarigan, Robinson 2005. Ekonomi Regional. Jakarta: PT Bumi Angkasa.

Utami, Christina Whidya, 2006, Manajemen Ritel, Strategi dan Implementasi Ritel Modern, Jakarta, Salemba Empat.

Levy, Michael dan Weitz Barton A. 1998. Retailing Management. U.S: Irwin McGraw-Hill, Lumpkin.

Tjiptono, Fandy. Andi. 2008. (ed. 3), Strategi Pemasaran, Yogyakarta.

Raharjo,Reza Haditya. 2015. Analisis Pengaruh Keberadaan Minimarket Modern Terhadap Kelangsungan Usaha Toko Kelontong di Sekitarnya. Skripsi, Fakultas Ekonomi dan Bisnis Universitas Diponogoro Semarang. 